\title{
Effect of Salt Solution on Plasticity and Permeability of Vietnam's Soil Liners
}

\author{
Nguyen Thi Nu, Do Minh Ngoc
}

\begin{abstract}
In Vietnam, there are a lot of landfills to block pollutants and one of materials used for impermeable liners is soil liners (soil - bentonite mixture). In order to use as impermeable liners, the properties of soil liners such as plasticity and permeability were affected by many salt solutions which are leaching from decomposition of waste materials in the landfills. Those salt solutions can reduce the stable of impermeable liners. So, this paper presents a series of experimental studies in the laboratory to investigate the effect of some salt solutions on the properties of compaction, consolidation and plasticity of soil liners. The experimental results indicated that the salt concentration effected complex on the Atterberg limits and the vertical coefficient of permeability. It also found that increase in the salt concentration from $0 N$ to $0.05 N$ cause increase in plasticity index, liquid limit and decrease in the vertical coefficient of permeability. After that, the increasing of the salt concentration up to $1 \mathrm{~N}$ resulted in decrease in the liquid limit and plasticity index and increase in the vertical coefficient of permeability increases.
\end{abstract}

Keywords: Soil liners, permeability, plasticity, compaction.

\section{INTRODUCTION}

In Vietnam, because of the growth rapidly of population and urbanization, the solid waste disposal increases rapidly and makes a serious environmental problem. The normal way to reduce this waste is to dispose in landfills. In the landfill, there are a lot of pollutants such us waste water, salt solutions from decomposition of waste materials (Kreith and Tchobanoglous, 2002). The pollutants of landfill can classify four groups such as dissolved organic matter, heavy metals, inorganic macro components and xenobiotic organic compounds (Christensen et al., 1994). The pollutants of waste in landfill can transfer to percolating water because of combination of microbial, chemical, physical processes in the waste (Christensen and Kjeldsen, 1989). The components of pollutants can be leached from the landfill to outside and may effect on the soil liners. So, it is necessary to study the effect of salt solution in the landfill on the soil liners in order to protect environment. In the landfill, the major environmental protects are to prevent the leachate of pollution into surface water and groundwater.

Revised Manuscript Received on February 05, 2020.

* Correspondence Author

Nguyen Thi Nu*, Department of Engineering Geology, University of Mining and Geology, Hanoi, Vietnam. Email: nguyenthinu@humg.edu.vn

Do Minh Ngoc, Faculty of Engineering, University of Transport Technology, Hanoi, Vietnam. Email: ngocdm@utt.edu.vn

(C) The Authors. Published by Blue Eyes Intelligence Engineering and Sciences Publication (BEIESP). This is an open access article under the CC BY-NC-ND license (http://creativecommons.org/licenses/by-nc-nd/4.0/)
The impermeable liners in the landfile can be used to limit percolation of leachate ground water. Soil materials can be used as impermable liners. The composition of soil materials include compacted clayey soil, soil - bentonite mixtures, Geosynthetic clay liners (GCL). Lee and Shackelford (2005) indicated that the higher quality bentonite Geosynthetic clay linners was more susceptible to chemical attack and increased more the hydraulic conductivity than the lower quality bentonite Geosynthetic clay linners . Albrecht and Cartwright (1989) investigate the properties of compacted earthen liner and found that the compacted earthen liner has low infiltration and low hydraulic conductivity.

The components of waste water affect almost all properties of soil liners. Oluremi at el. (2011) studied the influent of cyanide and trace quantity of heavy metals on geotechnical properties of lateritic soil and it found that the ions exchange or matures pore fluid influenced consistency index, compaction properties and CBR value. Shariatmadari et al. (2011) had studied $\mathrm{NaCl}, \mathrm{MgCl}_{2}, \mathrm{CaCl}_{2}$ effected to liquid limit, compaction, compression index, hydraulic conductivity of soil-bentonite mixtures as barriers. It was found that the higher cation valence and salt concentration can be decreased in liquid limit of soil liners and made the variation of compaction properties, compression index and hydraulic conductivity of soil. Ajalloeian et al., (2013) investigated some properties of fine soil effected by saline water. It was found that the increasing of pore wate salinity resulted in decrease in compression index, swelling index, and Atterberg limits and increase in shear strength parameter, and coefficient of consolidation. Arasan and Temel (2008) found that ammonium chloride $\left(\mathrm{NH}_{4} \mathrm{Cl}\right)$, potassium chloride $(\mathrm{KCl})$, copper sulphate $\left(\mathrm{FeSO}_{4}\right)$ and iron sulphate $\left(\mathrm{CuSO}_{4}\right)$ salt solutions effected the same variation on high plasticity clay. Ajitha et al., (2018) indicated that increase in the permeability of Amended clay liner cause by chromium.

From a literature previous studied, it found that engineering properties of soil liners are very different and effected by many components of pollutants. A little study has been made on the investigation the properties of soil bentonites liners at different salt solution. Moreover, from the previous studied, it can be found that the pollutants can be effected on the stable of impermeable liners. Not much work has been documented on effected of waste water (salt solutions) on the properties of soil liners in Vietnam. It needs to be researched more deeply to serve the sustainable development of human living environment. So, this paper aimed at studying the effect of commonly salt solutions on some properties of soil liners then indicating the variation in engineering properties of liners using local soil. 


\section{MATERIALS}

In this study, materials were used to make impermeable liners in the landfills were soil - bentonite mixture. The samples of soil were collected in boreholes from Hanoi, Vietnam. This soil exposed widely in the surface. The sample of soil was determined particle size, physical properties and compaction properties of soil in accordance with Vietnamese standard TCVN. Particle size, some physical properties and optimum water content (OMC), maximum dry density (MDD) of soil are provided in Table 1. From experiment results, it can be seen that the soil in firm state, composed of sandy clay with low plasticity. The compaction properties of soil also are showed in Figure 1.

Table 1: The physical properties of soil

\begin{tabular}{|c|c|c|c|c|c|}
\hline $\mathbf{N}^{0}$ & \multicolumn{2}{|c|}{ Properties of soil } & Symbol & Unit & Value \\
\hline \multirow{3}{*}{1} & \multirow{3}{*}{$\begin{array}{l}\text { Particle } \\
\text { size, \% }\end{array}$} & $1-0.05$ & \multirow{3}{*}{$\mathrm{P}$} & \multirow{3}{*}{$\%$} & 26.8 \\
\hline & & $0.05-0.005$ & & & 48.9 \\
\hline & & $<0.005$ & & & 24.3 \\
\hline 2 & \multicolumn{2}{|c|}{ Water content } & W & $\%$ & 26.3 \\
\hline 3 & \multicolumn{2}{|c|}{$\begin{array}{l}\text { Optimum water content } \\
\text { (OMC) }\end{array}$} & Wop & $\%$ & 20.0 \\
\hline 4 & \multicolumn{2}{|c|}{$\begin{array}{l}\text { Maximum dry density } \\
\text { (MDD) }\end{array}$} & $\gamma_{\text {cmax }}$ & $\mathrm{g} / \mathrm{cm}^{3}$ & 1.67 \\
\hline 5 & \multicolumn{2}{|c|}{ Specific gravity } & $\gamma_{\mathrm{s}}$ & $\mathrm{g} / \mathrm{cm}^{3}$ & 2.68 \\
\hline 6 & \multicolumn{2}{|c|}{ Liquid limit } & $\mathrm{W}_{\mathrm{L}}$ & $\%$ & 32.4 \\
\hline 7 & \multicolumn{2}{|c|}{ Plastic limit } & $\mathrm{W}_{\mathrm{P}}$ & $\%$ & 19.9 \\
\hline 8 & \multicolumn{2}{|c|}{ Plasticity Index } & $\mathrm{I}_{\mathrm{p}}$ & & 12.50 \\
\hline 9 & \multicolumn{2}{|c|}{ Liquidity index } & $\mathrm{I}_{\mathrm{S}}$ & & 0.51 \\
\hline
\end{tabular}

Bentonite is often used in Vietnam and made from Thai Binh MC ., JSC. The properties of bentonite are showed in Table 2.

Table 2: Properties of bentonite

\begin{tabular}{|l|l|l|}
\hline \multicolumn{2}{|c|}{ Properties of bentonite } & Value \\
\hline \multicolumn{1}{|c|}{ Specific gravity, $\mathrm{g} / \mathrm{cm}^{3}$} & 2.54 \\
\hline Liquid limit, \% & 210.4 \\
\hline \multicolumn{5}{|l|}{ Plastic Limit, \% } & 64.5 \\
\hline \multirow{4}{*}{$\begin{array}{l}\text { Chemical } \\
\text { components }\end{array}$} & $\mathrm{SiO}_{2}$ & $57.9 \%$ \\
\cline { 2 - 3 } & $\mathrm{Al}_{2} \mathrm{O}_{3}$ & $16.6 \%$ \\
\cline { 2 - 3 } & $\mathrm{Fe}_{2} \mathrm{O}_{3}$ & $2.17 \%$ \\
\cline { 2 - 3 } & $\mathrm{Na}_{2} \mathrm{O}+\mathrm{K}_{2} \mathrm{O}$ & $4.12 \%$ \\
\cline { 2 - 3 } & $\mathrm{CaO}+\mathrm{MgO}$ & $2.14 \%$ \\
\cline { 2 - 3 } & $\mathrm{LOI}(\mathrm{Loss}$ of ignition) & $8.00 \%$ \\
\hline
\end{tabular}

To study effect of salt solution on the soil - bentonite liner properties, bentonite was mixed with $15 \%$, $25 \%$ by weight of dry clayey soil. These mixtures were determined the optimum water content (OMC) and maximum dry density (MDD) in accodance with American standard ASTM D 698. The compaction results are provided in Figure 1 indicated that the optimum water content increases with increase in percentage of bentonit content otherwise maximum dry unit weight decreases.

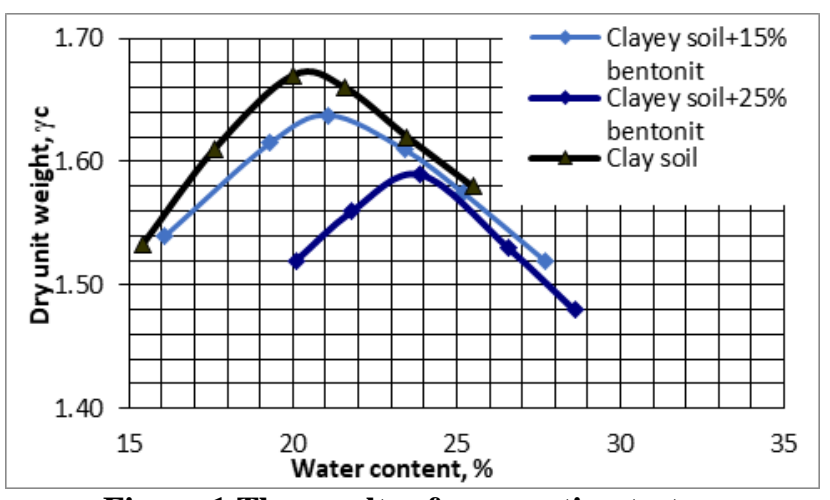

Figure 1.The results of compaction tests

\section{TESTING PROGRAM}

The soil was mixed with $0,15 \%$, and $25 \%$ bentonite at the optimum moisture content and maximum dry unit weight. Samples were prepared by blending with pure water or salt solutions with different concentration $(0.05 \mathrm{~N}, 0.1 \mathrm{~N}$ and $1 \mathrm{~N})$. The compacted mold immersed in a basin contains distilled water or salt solution with the same concentration that was prepared with it for a period of 120 hours to read moisture equilibrium before conducted the test. In this study, three salt solution were used $\mathrm{NaCl}, \mathrm{CaCl}_{2} ; \mathrm{FeCl}_{3}$.

The mixtures were prepared for Atterberg plastic limit tests. All mixture samples were incubated for five days. After that, the Atterberg plastic limits of these mixtures were determined in accordance with American standard ASTM D 4318.

In order to detemine the coefficient of permeability, the oedometer consolidation test was conducted according to American standard ASTM D2435 in the odermeter cell of $6.1 \mathrm{~cm}$ in diameter and 2.0 in height. Shariaatmadari et al. (2011) used consolidation test to investigate the compressibility and the hydralic conductivity properties of soil -bentonite mixtures. The test used pure water and salt solutions $\left(\mathrm{NaCl}, \mathrm{CaCl}_{2} ; \mathrm{FeCl}_{3}\right)$ in three concentrations of $0.05 \mathrm{~N}, 0.1 \mathrm{~N}$ and $1 \mathrm{~N}$. All samples were enclosed with full these solution immersion. The soil liners were saturated by pure water and salt solutions in five days before the test. The consolidation test used a load increment ration of 1 and the required load with a stress of 12.5, 25, 50,100, 200 and 400 $\mathrm{kPa}$. In the consolidation tesr, each load increment was maintained for at least 24 hours to ensure the completion of primary consolidation. From the consolidation results, the vertical coefficient of permeability of soil liners of each stress were calculated.

\section{RESULT AND DISCUSSION}

\section{A. Effect of salt solution on Plasticity of soil}

Figure 2, Figure 3 represent the variation of liquid limit, plasticity index as the concentration of inorganic salts $(\mathrm{NaCl}$, $\mathrm{CaCl}_{2} ; \mathrm{FeCl}_{3}$ ) in respective. 

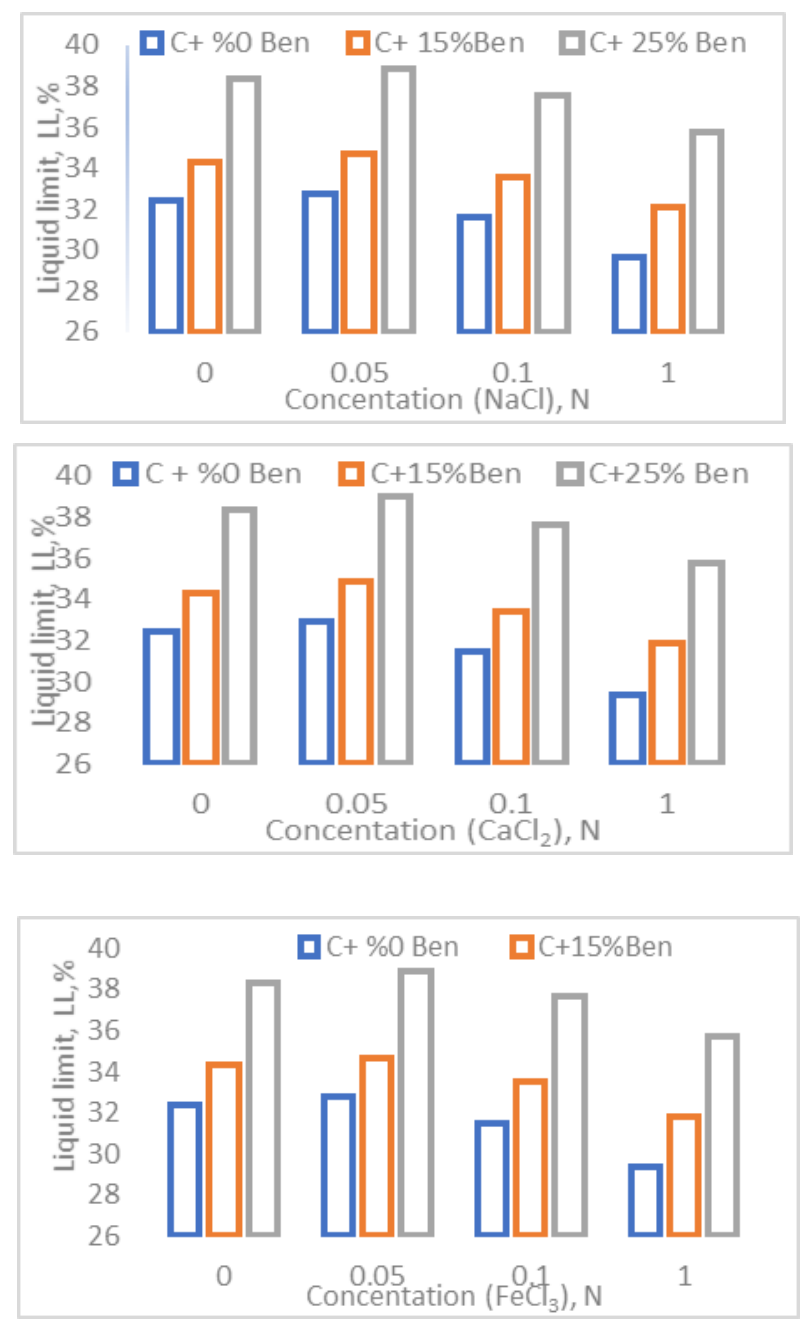

Figure 2. Effect of cation valance of $\mathrm{NaCl}, \mathrm{CaCl}_{2} ; \mathrm{FeCl}_{3}$ on liquid limit of soils
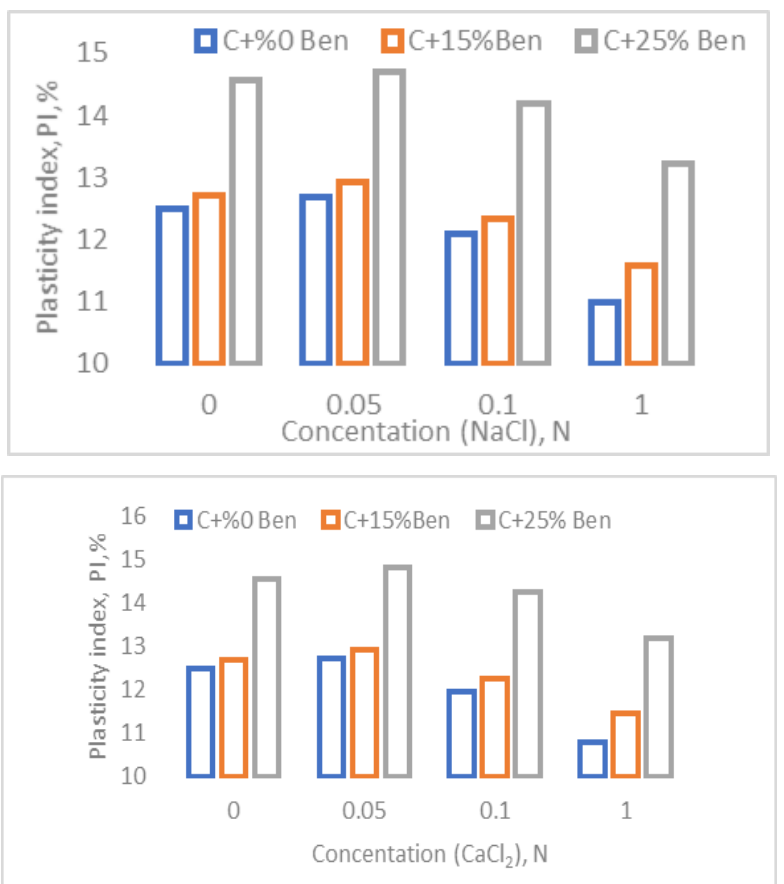

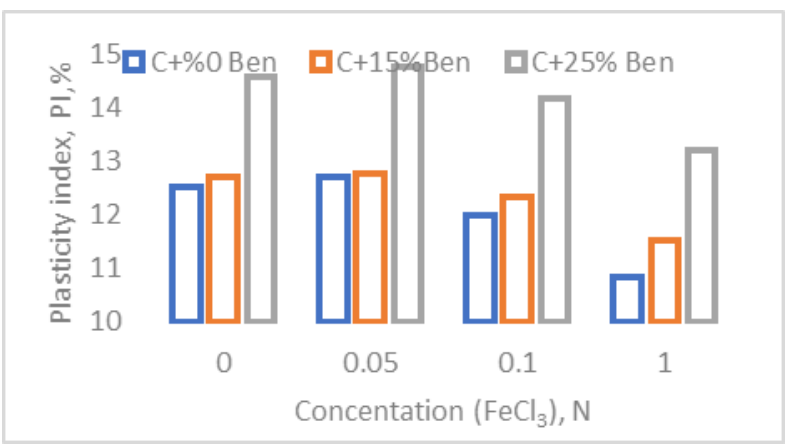

Figure 3. Effect of cation valance of $\mathrm{NaCl}, \mathrm{CaCl}_{2} ; \mathrm{FeCl}_{3}$ on plasticity index of soils

It was seen that the that both plasticity index and liquid limit increased as the salts concentration increase from 0 to $0.05 \mathrm{~N}$. It may be due the fact that the lower salts concentration made the increase in the diffuse double layer thickness and fabric changes. It is similar with the results of Janabi et al., (2017) that increase in the concentration of salt resulted in increase consistency limits. By increasing the salt concentration from $0.05 \mathrm{~N}$ to $1 \mathrm{~N}$, liquid limit and plasticity index of mixtures decreases. It may be be due to the fact that the diffuse double layer thickness decreases because of flocculation of clay particles. It is consistent with the results of Bowder and Daniel (1987) that the use of chemicals tends to decrease the the diffuse double layer thickness which caused decrease in repulsive and shrinked the soil skeleton and forces. It was also found that this reason made increase in the flocculation of clay particles and the dehydrated interlayer zone of expandable clays, which there after became a gritty or granular. This reason can be explainded by Sharma and Lewis (1994) that clay mineral layers has the net electrical forces and these forces were effected by the concentration valence of the cations and the increase of cation make in a reduction in net repulsive forces and causes clay particles to flocculates. Sivapullaiah, P.V (2005) indicated that through increased electrolyte concentration which reduced the diffuse double layer repulsion and brought the particles closer.

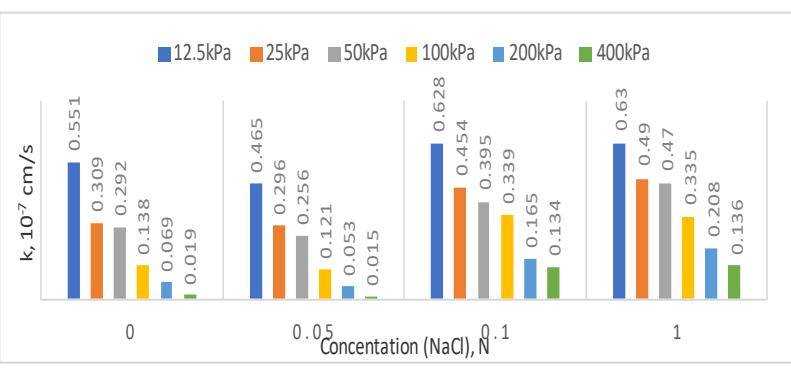

\section{B. Effect of salt solution on the coefficient of permeability}

The variation of permeability coefficient of soil - bentonite mixtures with different concentration of $\mathrm{NaCl}, \mathrm{CaCl}_{2} ; \mathrm{FeCl}_{3}$ are presented in Figure 4, Figure 5 and Figure 6.

a, 

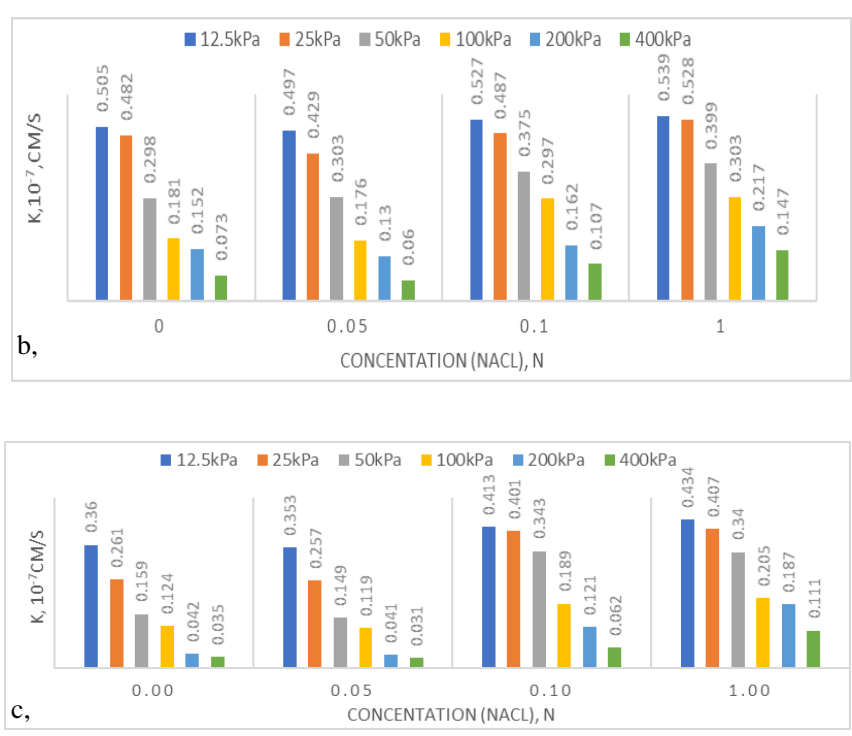

Figure 4. Variation of the coefficient of permeability as $\mathrm{NaCl}$ concentration. a, C+ $0 \%$ Ben; b, $-\mathrm{C}+15 \%$ Ben; c, $\mathrm{C}+25 \%$ Ben.
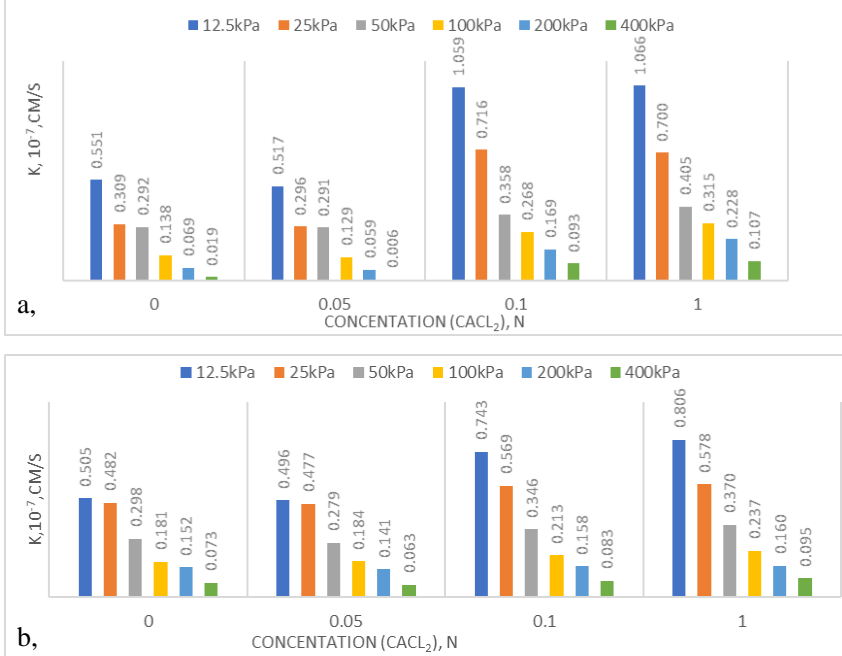

$\mathrm{b}$,

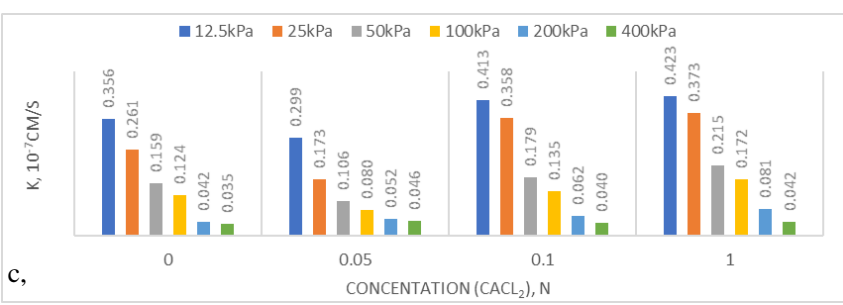

Figure 5. Variation of the coefficient of permeability as $\mathrm{CaCl}_{2}$ concentration. a, C+ 0\% Ben; b, - C+15\% Ben; c, $-\mathrm{C}+25 \%$ Ben.

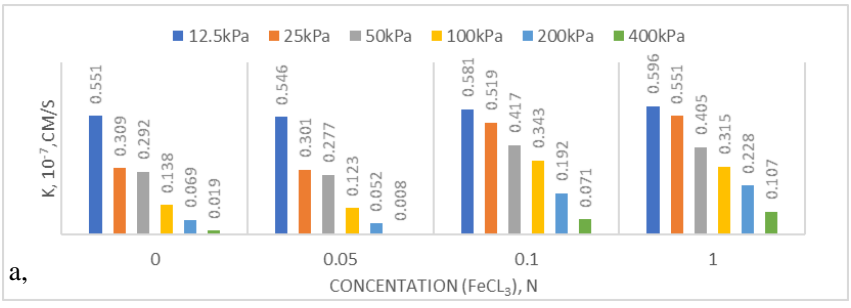

Retrieval Number: C6466029320/2020@BEIESP

DOI: 10.35940/ijeat.C6466.029320

Journal Website: www.ijeat.org
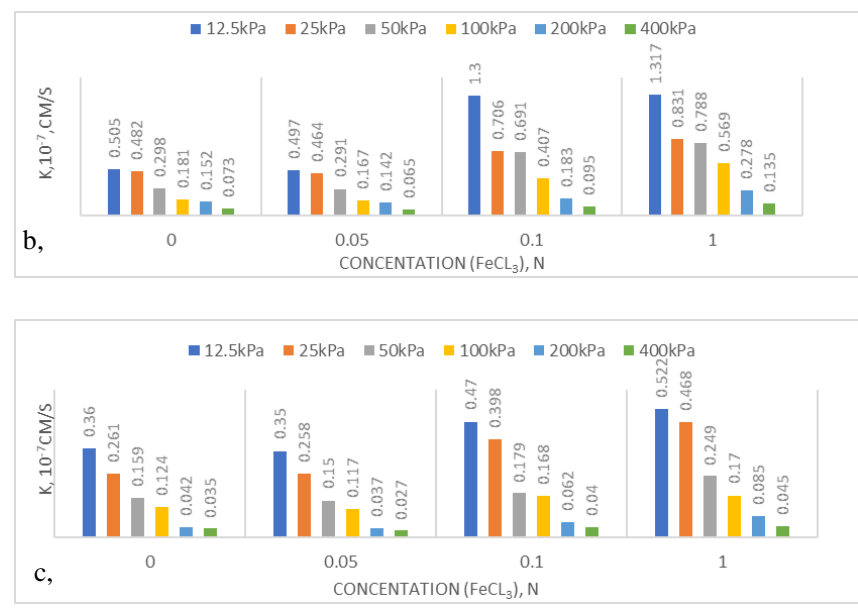

Figure 6. Variation of the coefficient of permeability as $\mathrm{FeCl}_{3}$ concentration at different pressure. a, C+ $0 \%$ Ben; b, $-\mathrm{C}+15 \%$ Ben; $c,-\mathrm{C}+25 \%$ Ben.

From the results are showed in Figure 3, 4, 5, it can be observed that the coefficient of permeability of soil bentonite mixtures varied and effected by the types of salt solution, the cation and the salt of concentration.

As similarity of plasticity index, increase in salt concentration up to $0.05 \mathrm{~N}$ resulted in decrease in the coefficient of permeability of soil - bentonite mixtures. This result agrees with results reported by some previous reseachers such us Yilmaz (2008), Arasan (2010), Al-Janabi et al.(2017) that the decrease in coefficient of permeability of these mixtures because of the increase in the thickness of diffuse double layer. By increase in salt concentration of $\mathrm{CaCl}_{2}, \mathrm{NaCl}$, and $\mathrm{FeCl}_{3}$ up to $1 \mathrm{~N}$, the coefficient of permeability of mixtures increases. It is consistent with the results of Ajitha et al., (2018) that increase in concentration of chromium and time resulted in increase in the permeability. It is concluded that hydraulic conductivity of mixtures by adding salt to the pore fluid and increasing its concentration (Shariatmadari at et, 2011) and increase the salt concentration made the decrease of the thickness of diffuse double layer resulting in flocculation of clay particles. Clay mineral in contact with certain chemical could makes large interlayer shrinkage and reduces the thickness of diffuse double layer (Quigley,1993). It was believed that the thickness of diffuse double layer decreased which led to flocculation of the clay particles, creating large pore channels which flow could occur because of the Gouy-Chapman theory by increasing the ion concentration (Mitchel, 1993; Gleason, 1997; Yilmaz, 2008)

In above figure, it can also be seen that increase in compression pressure levels resulted in decrease in the coefficient of permeability of soil - bentonite mixtures.

The effect of salt solution of $\mathrm{CaCl}_{2}$ and $\mathrm{FeCl}_{3}$ in the coefficient of permeability is more in comparison to the coefficient of permeability by $\mathrm{NaCl}$.

\section{CONCLUSION}

The compacted clay Liner used to protect the environmental protection purpose in the landfill and effected by many pollutants the waste. 
Based on the experiment results, the following observation and conclusion are made as follows:

1) Type of salt solutions ( $\mathrm{NaCl}, \mathrm{CaCl}_{2} ; \mathrm{FeCl}_{3}$ ) and the salt concentration effected on the consistency limits and the coefficient of permeability.

2) As the concentration of $\mathrm{NaCl}, \mathrm{CaCl}_{2} ; \mathrm{FeCl}_{3}$ increased from $0 \mathrm{~N}$ to $0.05 \mathrm{~N}$, the liquid limit and plasticity index increases otherwise the coefficient of permeability decreases.

3) The salt concentration ranged from $0.05 \mathrm{~N}$ to $1 \mathrm{~N}$, liquid limit and plasticity index decreases, the coefficient of permeability increases.

4) This is a basic document for designing linners in Landfills in Vietnam

\section{ACKNOWLEDGMENT}

We would like to thank the support of Ministry of Education and Training and Ha Noi University of Ming and Geology to complete this paper.

\section{REFERENCES}

1. Kreith, F., Tchobanoglous,G.(2002). Handbook of Solid Waste Management. 2nd Edition.

2. Christensen, T. \& Kjeldsen, P. (1989). Basic biochemical processes in landfills. In Sanitary Landfilling: Process, Technology and Environmental Impact. San Diego, CA, USA: Academic Press, pp. 29-49.

3. Albrecht, K.A. \& Cartwright, K., (1989). Infiltration and hydraulic conductivity of a compacted earthen liner. Groundwater 27 (1), 14-19

4. Oluremi, R. J., Solomon, I. A., Rebecca, A. O., and Solomon O. A (2011). "Assessment of Cassava waste water on the geotechnical properties lateritic soil". The Pacific Journal of Science and Technology, Vol. 13, issue-1.

5. Christensen, T.H., Kjeldsen, P., Albrechtsen, H.-J., Heron, G., Nielsen, P.H., Bjerg, P.L., and Holm, P.E., Attenuation of landfill leachate pollutants in aquifers, Crit. Rev. Environ. Sci. Technol., 24, 119, 1994.

6. Lee, J.M. and Shackelford, D.C. (2005). Impact of Bentonite Quality on Hydraulic Conductivity of Geosynthetic Clay Liners, Journal of Geotechnical and Geoenvironmental Engineering, Vol. 131, No. 1, January.

7. Shariatmadari, N., Salami,M., Fard, K.M. (2011). Effect of inorganic salt solutions on some geotechnical properties of soil-bentonite mixtures as barriers, International Journal of Civil Engineering. Vol. 9, No. 2, June.

8. Ajalloeian, R., Mansouri, H., Sadeghpour, H.A.(2013). Effect of Saline Water on Geotechnical Properties of Fine-grained Soil. Electronic Journal of Geotechnical Engineering 18:1419-1435. Vol. 18 [2013], Bund. G.

9. Arasan, S. and Yetimoglu, T. (2008). "Effects of inorganic salt solutions on the consistency limits of two clays". Turkish journal of Engineering, Environment and Science, Vol. 32, pp. 107-115.

10. Ajitha, A.R., Chandrakaran, S., Sheela Evangeline, Y.(2018). Effect of Chromium on The Engineering Properties of Amended Clay Liner. International Journal of Engineering and Advanced Technology (IJEAT). ISSN: 2249 - 8958, Volume-7 Issue-3, February 2018.

11. Khalid, R., Al-Janabi,M., Abdullah, M.B. (2017). Effects of inorganic salt solution on some properties of compacted clay liners. Journal of Engineering Science and Technology, Vol. 12, No. 12 (2017) 3188 3202.

12. Bowders, J.J.; and Daniel, D.E. (1987). Hydraulic conductivity of compacted clay to dilute organic chemicals. Journal of Geotechnical Engineering, 113(12), 1432-1448.

13. Sharma, H.D.; and Lewis, S.P. (1994), Waste containment system, Waste stabilization and landfill, design and evaluation. John Wiley and sons Inc., Canada

14. Sivapullaiah, P.V. and Manju, A. (2005). Kaolinite-alkali interaction and effects on basic properties. Geotechnical and Geological Engineering, 23(5), 601-614.

15. Yilmaz, G.; Yetimoglu, T. and Arasan, S. (2008). Hydraulic conductivity of compacted clay liners permeated with inorganic salt solutions. Waste management \& research, ISWA, 26(5),464-73.
16. Arasan, S. (2010). Effect of chemicals on geotechnical properties of clay liners: A review. Research Journal of Applied Sciences, Engineering and Technology, 2(8), 765-775.

17. Quigley, R.M.: 1993, Clay minerals against contaminant migration, Geotechnical News, North American Geotechnical Community, 11, 44-46.

18. Mitchell, J.K.: 1993, Fundamentals of Soil Behaviour, 2nd ed., Wiley, New York

19. Gleason, M., Daniel, D.E. and Eydholt, G.R.: 1997, Calcium and sodium bentonite for hydraulic containment applications. Journal of Geotechnical and Geo-environmental Eng. ASCE, 123:5, 438-445.

\section{AUTHORS PROFILE}

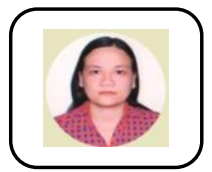

Nguyen Thi Nu, Doctor and Lecturer in Department of Engineering Geology, University of Mining and Geology in Hanoi, Vietnam.

Do Minh Ngoc, Doctor and Lecturer in Faculty of Engineering, University of Transport Technology, Hanoi, Vietnam. Email:, ngocdm@utt.edu.vn 